\title{
Heterotrophic ammonium removal by a novel hatchery isolate Acinetobacter calcoaceticus STB1
}

\author{
Omer Faruk Sarioglu ${ }^{\text {a,b }}$, Rabia Suluyayla ${ }^{\text {b,c }}$, Turgay Tekinay ${ }^{\text {a,b,* }}$ \\ ${ }^{a}$ Bilkent University, Department of Materials Science and Nanotechnology, Bilkent, Ankara 06800, Turkey \\ ${ }^{\mathrm{b}}$ Laboratory of Sustainable Technologies, Bilkent University, UNAM-Institute of Materials Science and Nanotechnology, Bilkent, Ankara 06800, Turkey \\ ' Bilkent University, Department of Molecular Biology and Genetics, Bilkent, Ankara 06800, Turkey
}

\section{A R T I C L E I N F O}

\section{Article history:}

Received 23 March 2012

Received in revised form 19 April 2012

Accepted 20 April 2012

Available online 16 May 2012

\section{Keywords:}

Acinetobacter calcoaceticus STB1

Heterotrophic ammonium removal

16S rRNA phylogenetic analysis

Artemia nauplii

\begin{abstract}
A B S T R A C T
A novel bacterial strain, STB1, was isolated from a commercial sea bass hatchery and found to display high heterotrophic ammonium removal characteristics at different concentrations of ammonium $\left(\mathrm{NH}_{4}^{+}-\mathrm{N}\right)$. The species identity of STB1 was determined via 16S rRNA gene sequence analysis to be Acinetobacter calcoaceticus. We evaluated ammonium removal characteristics of STB1 at varying ammonium concentrations, and observed that STB1 can almost completely remove ammonium at low $\left(50 \mathrm{mg} \mathrm{l}^{-1}\right)$, and medium (100 $\mathrm{mg} \mathrm{l}^{-1}$ ) concentrations within $72 \mathrm{~h}$, while $45 \%$ ammonium removal was observed at a higher concentration $\left(210 \mathrm{mg} \mathrm{l}^{-1}\right)$ during the same period. Trace amount of the metabolized ammonium was converted to nitrite or nitrate and $22.16 \%$ of total nitrogen was incorporated into cell biomass, while $4.34 \%$ of total nitrogen was initially incorporated into cell biomass and subsequently released to the supernatant fraction in the $100 \mathrm{mg} \mathrm{l}^{-1}$ sample. Most of the remaining conversion products are expected to be gaseous denitrification products. Toxicological studies with Artemia salina (brine shrimp) nauplii revealed that STB1 strain is non-toxic to Artemia larvae, which suggests that STB1 can be safely and efficiently utilized in water quality enrichment in aquatic ecosystems.
\end{abstract}

(c) 2012 Elsevier Ltd. All rights reserved.

\section{Introduction}

One of the main problems in water quality management is the inadequate remediation of high ammonium and nitrogen concentrations of aquatic systems, which is primarily caused by industrial, agricultural, urban or domestic wastewater efflux into natural freshwater or marine environments (Taylor et al., 2009). Ammonia is one of the most toxic nitrogenous compounds to aquatic life and exists in water in two forms: as non-dissociated ammonia $\left(\mathrm{NH}_{3}\right)$ or mostly as ammonium ion $\left(\mathrm{NH}_{4}^{+}\right)$; the latter of which is found to be severely toxic to aquatic organisms (WHO, 1990; US EPA, 2009). The acute toxicity of ammonia is affected by several environmental factors such as water temperature, $\mathrm{pH}$ and salinity, as well as the amount of dissolved oxygen in water. Therefore, ammonia concentrations between 2 and $10 \mathrm{mg} \mathrm{l}^{-1}$ are usually lethal to most

Abbreviations: OD, Optical Density; SEM, Scanning Electron Microscopy; PCR, Polymerase Chain Reaction; LB, Lysogeny Broth/Luria Bertani; NCBI, National Center for Biotechnology Information.

* Corresponding author. Bilkent University, Department of Materials Science and Nanotechnology, Bilkent, Ankara 06800, Turkey. Tel.: +90 312290 3573; fax: +90 3122664563.

E-mail address: ttekinay@bilkent.edu.tr (T. Tekinay). aquatic life, and the acceptable level for ammonia in drinking water is designated as $1.5 \mathrm{mg} \mathrm{l}^{-1}$ by the U. S. Environmental Protection Agency (US EPA, 2009). Other forms of nitrogen, such as nitrite and nitrate, can also be highly toxic to aquatic life, with nitrite in particular being highly toxic to most aquatic organisms. However, nitrite is not stable in aquatic environments and is rapidly oxidized to nitrate, resulting in relatively low nitrite concentrations in water (Russo, 1985). Nonetheless, both compounds are characterized with relatively low acceptable concentration thresholds. According to the US EPA, the sum of the nitrite and nitrate concentration in drinking water should be lower than $10 \mathrm{mg} \mathrm{l}^{-1}$, and the separate limits of nitrite and nitrate are designated as $1 \mathrm{mg} \mathrm{l}^{-1}$ and $10 \mathrm{mg} \mathrm{l}^{-1}$, respectively (NJDEP, 1997). Since the presence of free ammonia in aquatic systems constitutes a potential health hazard, efficient removal of ammonia and other nitrogenous compounds from fresh and saltwater environments is highly desirable (US EPA, 1993; Taylor et al., 2009). Many methods are currently utilized to reduce the amount of ammonia present in water, and biological nitrogen removal is a common approach for ammonium remediation of both natural aquatic systems and industrial wastewater as it is significantly cheaper, more effective and devoid of undesirable sideproducts compared to the alternative physical and chemical remediation processes such as ion exchange and adsorption (US 
EPA, 1993; Rostron et al., 2001; Jorgensen and Weatherley, 2003; Khardenavis et al., 2007; Andrade do Canto et al., 2008).

The biological remediation process of ammonium primarily involves its conversion into nitrogen, which is carried out mostly by autotrophic nitrifiers and heterotrophic denitrifiers (Sinha and Annachhatre, 2006; Zhao et al., 2010). Autotrophic nitrifiers oxidize ammonium and convert it to nitrification products, such as nitrite or nitrate, while heterotrophic denitrifiers utilize those nitrification products and convert them to gaseous denitrification products, especially nitrogen gas $\left(\mathrm{N}_{2}\right)$. Some heterotrophic denitrifiers have the ability to utilize ammonium as well, and those can simultaneously carry out both nitrification and denitrification. While heterotrophic microorganisms are tolerant to, or even dependent on, high concentrations of ammonium and organic matter, autotrophic microorganisms are generally incapable of surviving in such environments (Joo et al., 2005). Recent studies have highlighted the fact that nitrogenous wastewater sources may be relatively high in organic carbon and nitrogen. Therefore, ammonium removal by heterotrophic denitrifiers seems to be particularly advantageous, especially since autotrophic nitrifiers are usually sensitive to high amounts of ammonium and carbon and have difficulty growing in these conditions (Yang et al., 2011). A wide variety of bacteria has been characterized with regards to their potential use in bioremediation of ammonium or other nitrogenous waste products, which mostly act by converting the residual ammonia into nitrogen gas under heterotrophic conditions such as Alcaligenes faecalis, Acinetobacter calcoaceticus, Thiosphaera pantotropha, Bacillus sp., Microvirgula aerodenitrificans, Pseudomonas stutzeri, Pseudomonas putida, Comamonas sp. and Diaphorobacter sp. (Taylor et al., 2009; Zhao et al., 2010; Yang et al., 2011). Furthermore, some bacterial species have oligotrophic characteristics which can survive in low nutrient conditions with minimal growth and low rates of metabolism, however, some members of those bacteria tend to be heterotrophic under nutrient-rich conditions (Schmidt and Schaechter, 2011).

Artemia (commonly known as brine shrimp) is widely used as live feed in aquatic ecosystems, and the nauplius stage in particular is commonly utilized as live feed in marine hatcheries ( $\mathrm{Wu}$ and Chu, 2007). Artemia can survive exposure to wide ranges of salinity, temperature and adverse environmental conditions; which combined with a short life cycle and the relative ease of rearing, make Artemia a very suitable model organism in ecotoxicity tests (Nunes et al., 2006).

This work details the isolation of a novel A. calcoaceticus strain STB1 from a hatchery and describes its potential for removing ammonium in industrial wastewater systems or natural ammonium-contaminated environments, with in vitro experiments and in vivo tests by using Artemia salina nauplii survival and growth rates as an indicator.

\section{Materials and methods}

\subsection{Culture media and isolation of STB1}

Brackish water samples were collected from a commercial sea bass farm in Mugla, Turkey and enriched for ammonia-reducing bacteria by using a medium containing $1.3 \mathrm{~g}$ of $\left(\mathrm{NH}_{4}\right)_{2} \mathrm{SO}_{4}, 0.5 \mathrm{~g}$ of $\mathrm{K}_{2} \mathrm{PO}_{4}, 3.8 \mathrm{mg}$ of FeNaEDTA, $0.1 \mathrm{mg}$ of $\mathrm{NaMoO}_{4} .2 \mathrm{H}_{2} \mathrm{O}, 0.1 \mathrm{mg}$ of $\mathrm{ZnSO}_{4} .7 \mathrm{H}_{2} \mathrm{O}, 0.2 \mathrm{mg}$ of $\mathrm{MnCl}_{2}, 0.05 \mathrm{~g}$ of $\mathrm{MgSO}_{4}, 4 \mathrm{mg}$ of $\mathrm{CaCl}_{2}$, $0.002 \mathrm{mg}$ of $\mathrm{CoCl}_{2} \cdot 6 \mathrm{H}_{2} \mathrm{O}$ and $0.02 \mathrm{mg}$ of $\mathrm{CuSO}_{4} \cdot 5 \mathrm{H}_{2} \mathrm{O}$ in $1 \mathrm{~L}$ of distilled water (Nejidat, 2005). Autotrophic or oligotrophic bacterial growth was aimed by the use of a $\mathrm{N}$-supplemented, $\mathrm{C}$-free medium. The $\mathrm{pH}$ of the medium was adjusted to $7.8-8$ via $\mathrm{K}_{2} \mathrm{CO}_{3}$ and supplied with either no additional salts (low salt medium, LS), $300 \mathrm{mM} \mathrm{NaCl}$ (high salt medium, HS) or $600 \mathrm{mM} \mathrm{NaCl}$ (sea salts medium, SS). All reagents utilized in this study were purchased from Sigma-Aldrich (USA). Brackish water samples were then inoculated $(6 \% \mathrm{v} / \mathrm{v})$ in all three media and incubated at $125 \mathrm{rpm}$, $30{ }^{\circ} \mathrm{C}$ for 33 days. $50 \%$ of media for each culture were replaced every five days and $\mathrm{pH}$ was maintained in the $7.8-8$ range via $\mathrm{K}_{2} \mathrm{CO}_{3}$. Concentrations of ammonia, nitrate and nitrite were measured by their respective test kits (Merck Ammonium Cell Test 14559, Merck Nitrate Cell Test 14563 and Merck Nitrite Cell Test 14547; Merck, USA). Samples were streaked on LS, HS and SS agar plates every five days and incubated at $30{ }^{\circ} \mathrm{C}$ for 5 days. All tests were done in triplicate. The term "survival" was used to indicate minimal growth of different isolates. While low survival rates were observed in the LS and HS media, a higher survival rate was observed in the SS medium sample at the end of this time period, and the potential ammonium-oxidizing isolate obtained from this plate was designated STB1.

\section{2. $16 S$ rRNA gene sequence analysis}

The species identity of STB1 was determined via 16S rRNA gene sequencing. DNA isolation was carried out via DNeasy Blood \& Tissue Kit (QIAGEN, Germany). For the PCR amplification and further sequencing, a modified protocol in which $1.25 \mathrm{U}$ Platinum Taq polymerase, $0.2 \mathrm{mM}$ dNTP, 0.4 pmol T3 (ATTAACCCTCACTAAAGGGA) and T7 (TAATACGACTCACTATAGGG) primers encompassing the entire $16 \mathrm{~S}$ gene, $1.5 \mathrm{mM} \mathrm{MgCl}$ and $1 \times$ Taq buffer were used in $50 \mu \mathrm{l}$ volumes (Rijpens et al., 1998). The PCR steps were carried out as follows; initial denaturation step of $96{ }^{\circ} \mathrm{C}$ for $5 \mathrm{~min}$ and 30 cycles of denaturation at $96{ }^{\circ} \mathrm{C}$ for $30 \mathrm{~s}$, annealing at $55^{\circ} \mathrm{C}$ for $30 \mathrm{~s}$, elongation at $72{ }^{\circ} \mathrm{C}$ for $30 \mathrm{~s}$ and a final elongation step for $72{ }^{\circ} \mathrm{C}$ for $5 \mathrm{~min}$. Sequencing was done via 3130xl Genetic Analyzer, with the help of BigDye Terminator v3.1 Cycle Sequencing Kit (Applied Biosystems, USA). For analysis, ABI 3130xl Genetic Analyzer was utilized. The $16 \mathrm{~S}$ rRNA sequence of the isolate was analyzed by NCBI's Bacterial Blast (http://www.ncbi.nlm.nih.gov) and TreeDyn software was utilized to construct and visualize a phylogenetic tree.

\subsection{Heterotrophic ammonium removal experiments}

After deciding STB1 is a heterotrophic microorganism rather than an autotrophic one, a modified basal salts medium was utilized to grow STB1 in shaking cultures. The ingredients of the basal salts medium are as follows: $6.3 \mathrm{~g} \mathrm{l}^{-1} \mathrm{Na}_{2} \mathrm{HPO}_{4}, 3 \mathrm{~g} \mathrm{l}^{-1}$ $\mathrm{KH}_{2} \mathrm{PO}_{4}, 0.5 \mathrm{~g} \mathrm{l}^{-1} \mathrm{NaCl}, 2 \mathrm{~g} \mathrm{l}^{-1}$ glucose (anhydrous), and 30\% of trace elements solution that consists of: $6.1 \mathrm{~g} \mathrm{l}^{-1} \mathrm{MgSO}_{4}, 3 \mathrm{~g} \mathrm{l}^{-1} \mathrm{H}_{3} \mathrm{BO}_{3}$, $0.5 \mathrm{~g} \mathrm{l}^{-1} \mathrm{MnCl}_{2}, 0.05 \mathrm{~g} \mathrm{l}^{-1} \mathrm{CaCl}_{2}, 0.03 \mathrm{~g} \mathrm{l}^{-1} \mathrm{FeSO}_{4} .7 \mathrm{H}_{2} \mathrm{O}, 0.03 \mathrm{~g} \mathrm{l}^{-1}$ $\mathrm{CuCl}_{2}, 0.03 \mathrm{~g} \mathrm{l}^{-1} \mathrm{ZnCl}_{2}$. Varying amounts of ammonium (in the form of $\mathrm{NH}_{4} \mathrm{Cl}$ ) were added to the basal medium for different samples. No additional carbon and nitrogen sources were utilized. STB1 cell cultures were inoculated in this medium and incubated for $72 \mathrm{~h}$ at $125 \mathrm{rpm}$ and $30{ }^{\circ} \mathrm{C}$. Ammonium removal efficiencies at different concentrations were determined by adjusting initial ammonium concentration to 50,100 and $210 \mathrm{mg} \mathrm{l}^{-1}$, representing low, medium and high concentrations respectively. Periodically, samples were collected to analyze changes in growth, ammonium, nitrite and nitrate. Bacterial growth rates were determined by $\mathrm{OD}_{600}$ measurements and ammonium, nitrite and nitrate concentrations in the samples were determined by the spectrophotometric test kits of Merck (Merck Ammonium Cell Test 14559, Merck Nitrate Cell Test 14563 and Merck Nitrite Cell Test 14547). Before applying the tests, samples were centrifuged for $5 \mathrm{~min}$ at $4,000 \mathrm{rpm}$ and $4{ }^{\circ} \mathrm{C}$, and supernatants were extracted and transferred to test tubes. Pellets were also discarded and transferred to $1.5 \mathrm{ml}$ centrifugation tubes. Pellet samples were stored at $4{ }^{\circ} \mathrm{C}$ for further use. 
Supernatants were used in analytical measurements of ammonium, nitrite and nitrate. All tests were done in triplicate. Experiments were repeated at least three times.

\subsection{Determination of TN incorporated into cell biomass}

Stored pellets of bacteria grown in $100 \mathrm{mg} \mathrm{l}^{-1}$ ammonium containing medium were utilized for detection of the total nitrogen amount incorporated into cell biomass and to the supernatant fraction from bacterial cells during the heterotrophic ammonium removal process. Samples were analyzed using an elemental analyzer for their TN content (Flash 2000 Organic Elemental Analyzer, Thermo Scientific USA) after dehydration and granulation of the cell pellets (Fagerbakke et al., 1996). The conversion of TN amount in the unit of $\mathrm{mg} \mathrm{l}^{-1}$ was based on the results of the total dry weight of bacteria in a $1 \mathrm{~L}$ growing medium. All tests were done in triplicate.

\subsection{Scanning Electron Microscopy (SEM)}

STB1 was inoculated in $5 \mathrm{ml} \mathrm{SS}$ medium containing $1 \mathrm{~cm}^{2}$ bioball pieces and incubated for 7 days at $125 \mathrm{rpm}$ and $30^{\circ} \mathrm{C}$. The bacterial plaques were fixed by a protocol similar to Greif and colleagues' (Greif et al., 2010). Initially, the bacterial plaques from the overnight cultures were washed twice with PBS buffer. Fixation of the cells was provided by incubating in 2.5\% glutaraldehyde in PBS for overnight at room temperature. Then the plaques were rewashed twice by PBS. Dehydration of the samples was done by slowly exchanging them in a 30\%-95\% series of ethanol. The plaques were coated with $10 \mathrm{~nm}$ gold-palladium before imaging the samples. A Quanta 200 FEG scanning electron microscope (FEI Instruments, USA) was used for taking the SEM images.

\subsection{Studies on Artemia nauplii}

A. salina cysts were purchased from a Taiwanese manufacturer (Artemia International Co., Ltd.) and were added to $1.5 \mathrm{~L}$ of autoclaved sea salt medium (35 $\mathrm{g} \mathrm{l}^{-1} \mathrm{NaCl}$ ) to facilitate hatching. After hatching of $A$. salina cysts and initial development of the nauplius larvae for 2 days, equal amounts of Artemia nauplii were transferred to two different environments each with a total volume of $200 \mathrm{ml}$, one containing $A>$. calcoaceticus strain of STB1 $\left(2.8 \times 10^{5} \mathrm{cfu} \mathrm{ml}^{-1}\right)$, and one containing no additional bacteria. The aeration was provided by aerators. Survival of Artemia nauplii larvae was monitored each day. Samples were taken at days 0, 3, 5 and 7 following hatching for survival percentage and individual length measurements of the nauplii. All tests were done in five replicates. Experiments were repeated at least three times.

\subsection{Statistical analysis}

Student's t-test was applied for statistical analyses. Analyses were done by using the software Minitab Version 13.2 (Minitab Inc., USA) at a 0.05 level of probability.

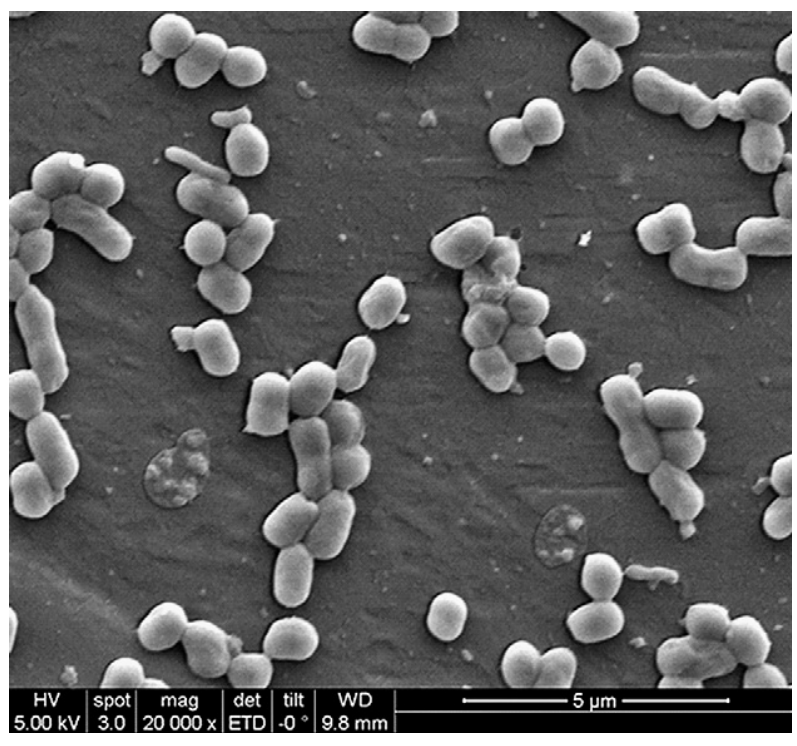

Fig. 2. Scanning Electron Microscope (SEM) image of A. calcoaceticus STB1.

\section{Results and discussion}

\subsection{Isolation and preliminary characterization of STB1}

In this study, we describe the isolation and identification of a novel $A$. calcoaceticus strain designated as STB1. Brackish water samples collected from a commercial sea bass farm were inoculated in a N-supplemented, C-free growth medium for isolation of autotrophic or oligotrophic bacteria. Samples were incubated at standard conditions and aliquots were taken periodically to examine bacterial survival on LB-agar plates. At the end of 33 day, STB1 was observed to show better survival compared to other isolates and was therefore chosen for further studies to evaluate its ammonium removal potential. Initially, STB1 grown at lower concentrations of ammonium ( $\leq 10 \mathrm{mg} \mathrm{l}^{-1}$, data not shown) in both heterotrophic and autotrophic conditions to determine which condition is better for ammonium removal by this isolate. While STB1 isolate displayed promising results for heterotrophic ammonium removal (complete removal of ammonium occurred in $72 \mathrm{~h}$ ), minimal change was observed for ammonium concentrations in autotrophic conditions. This isolate was therefore chosen for heterotrophic ammonium removal experiments at higher concentrations of ammonium and we sought to identify its phylogeny.

\subsection{Phylogenetic analysis and SEM images}

16S rRNA gene sequencing analysis was performed to identify the phylogeny of the STB1 strain. A sequence of 1085 bp 16S rRNA was obtained from PCR and an accession number of JQ653966 was received from GenBank. STB1 was determined to be a member of the species A. calcoaceticus, with $98 \%$ identity according to NCBI's

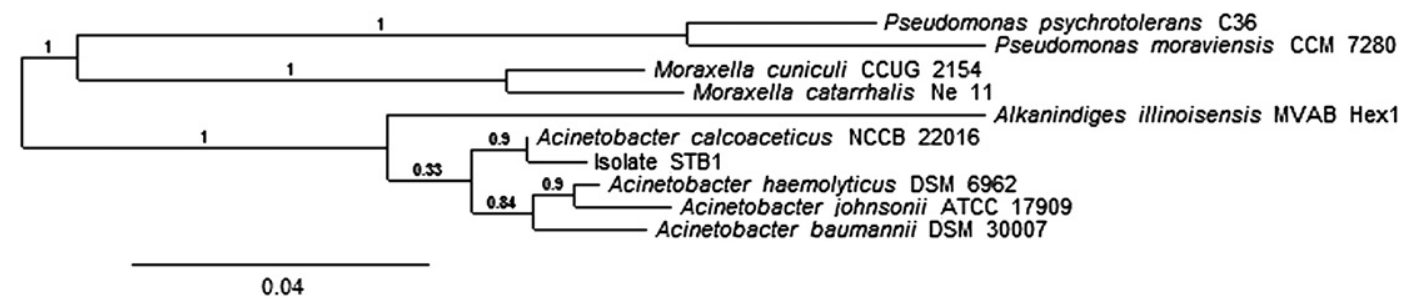

Fig. 1. Phylogenetic tree of the STB1 strain according to $16 \mathrm{~S}$ rRNA gene sequencing analysis. 


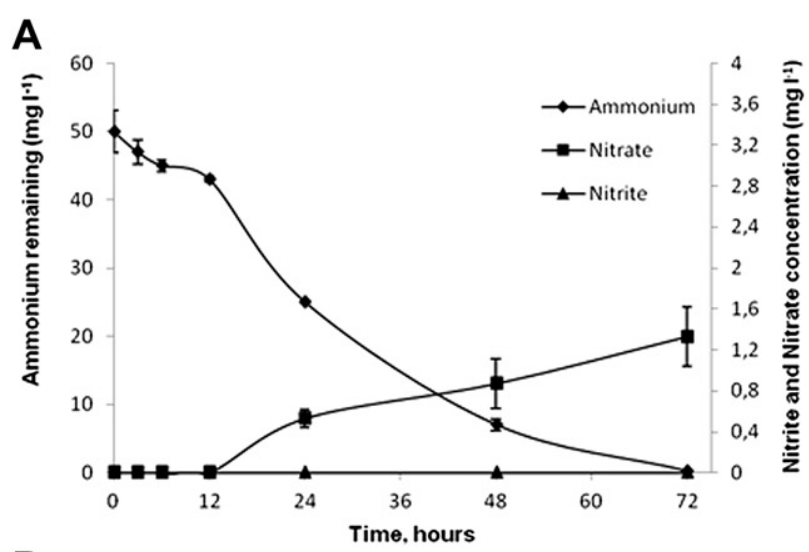

B
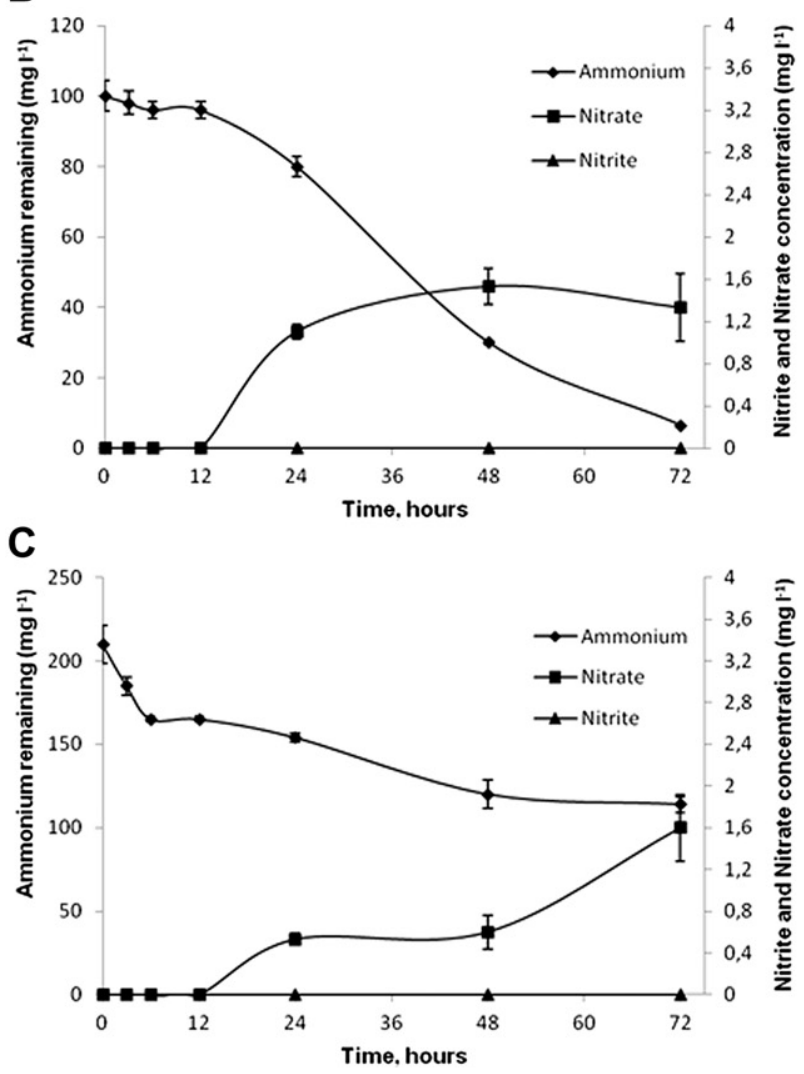

Fig. 3. The decrease in ammonium; and increase in nitrate and nitrite concentrations, with the initial ammonium levels of (A) $50 \mathrm{mg} \mathrm{l}^{-1}$, (B) $100 \mathrm{mg} \mathrm{l}^{-1}$ (C) $210 \mathrm{mg} \mathrm{l}^{-1}$ in 72 h. Error bars represent means \pm S.E.M of three replicates.

Bacterial Blast algorithm (http://www.ncbi.nlm.nih.gov). The phylogenetic tree of STB1 is shown in Fig. 1. SEM images of STB1 were taken to examine the biofilm-forming capability of the isolate after fixing STB1 bacterial cells attached to bioballs at the end of a 7-day growth period. Fig. 2 shows that the bacterial cells are physically close to each other, but there was no sign for biofilm formation or cellular fusion. The general morphological properties were very similar to other strains of $A$. calcoaceticus, with nearidentical shape and structure (Zhao et al., 2010).

\subsection{Heterotrophic ammonium removal capability of STB1}

STB1 isolate exhibited efficient heterotrophic ammonium removal at each concentration tested, though at higher concentrations $\left(210 \mathrm{mg} \mathrm{l}^{-1}\right.$ ) ammonium removal rate slowed down after $48 \mathrm{~h}$ and could not pass the desired threshold of $50 \%$ removal at the end of $72 \mathrm{~h}$. It was observed that the initial ammonium concentration is inversely proportional to the percentile ammonium removal capability in $72 \mathrm{~h}$ (Fig. 3). The isolate displayed $100 \%$ ammonium removal for the $50 \mathrm{mg} \mathrm{l}^{-1}$ sample, 93\% ammonium removal for the $100 \mathrm{mg} \mathrm{l}^{-1}$ sample and $45 \%$ ammonium removal for the $210 \mathrm{mg} \mathrm{l}^{-1}$ sample. The sum of nitrite and nitrate, or their separate concentrations were below the legal limits for drinking water (NJDEP, 1997). Nitrite concentration was below the detection limit and therefore assumed to be minimal. Nitrate concentrations were very close in each sample and between 1 and $2 \mathrm{mg} \mathrm{l}^{-1}$ at the end of $72 \mathrm{~h}$ growth period (Fig. 3).

\subsection{TN analysis}

Total Nitrogen (TN) analysis was done to the $100 \mathrm{mg} \mathrm{l}^{-1}$ sample to determine the percentage of ammonia incorporated into the cell biomass during heterotrophic ammonium removal. TN analysis revealed that $22.16 \%$ of ammonium was introduced to cell biomass, while $4.34 \%$ of TN was initially incorporated into cell biomass and subsequently released to the supernatant fraction during cell growth in $72 \mathrm{~h}$ (Table 1 ). Most of the remaining conversion products were expected to be gaseous denitrification products, a prediction supported by the high denitrification capability of A. calcoaceticus in a previous study (Zhao et al., 2010).

\subsection{Applicability of STB1 in aquatic ecosystems}

We compared the effects of $A$. calcoaceticus strain STB1 on the growth and survival of Artemia nauplii with a control sample under identical growth conditions but without STB1 inoculation. The survival rates and total lengths of Artemia nauplius specimens were similar during 7 days of growth period and no significant difference was observed between those samples therefore, STB1 strain is found to be non-toxic for the nauplius development in A. salina (Table 2). The survival of larvae was sharply decreased for both samples after 5 days however, such decrease is found as usual compare to a previous study (Verschuere et al., 1999). This promising result supports our suggestion of this strain to be utilized safely in aquatic ecosystems as a heterotrophic ammonium remover in addition to the industrial applications. We believe this strain has a high potential to be used in recirculating aquaculture farms and other industrial settings for ammonia removal. Since it is isolated from a hatchery and nitrite or nitrate accumulation is minimal, we believe STB1 could thrive in these conditions and

Table 1

Conversion of nitrogen by removal of ammonium by Acinetobacter calcoaceticus STB1 in $72 \mathrm{~h}$ (in terms of $\mathrm{mg} \mathrm{l}^{-1}$ ).

\begin{tabular}{|c|c|c|c|c|c|}
\hline & $\mathrm{NH}_{4}^{+}-\mathrm{N}$ & $\mathrm{NO}_{2}^{-}-\mathrm{N}$ & $\mathrm{NO}_{3}^{-}-\mathrm{N}$ & Intracellular $\mathrm{N}$ & TN loss of cell biomass \\
\hline Initial & $99.87 \pm 7.62$ & - & - & $8 \pm 0.11$ & - \\
\hline Final & $6.54 \pm 0.05$ & - & $1.33 \pm 0.55$ & $30.16 \pm 1.18$ & $4.34 \pm 0.6$ \\
\hline
\end{tabular}

-, Below detectable limits.

Means and standard deviations were placed together in the form of mean of three different replicates $\pm S D$.

TN loss of cell biomass = Maximum level of TN in cell biomass - latest level of TN in cell biomass. 
Table 2

Average survival and individual length of Artemia salina nauplii. ${ }^{a}$

\begin{tabular}{lllc}
\hline Time & Treatment & Survival $(\%)$ & Individual length $(\mu \mathrm{m})$ \\
\hline Day 0 & Control & $100 \pm 0$ & $428.3 \pm 38.68$ \\
& STB1 & - & - \\
Day 3 & Control & $68.7 \pm 5.9$ & $937 \pm 191.4$ \\
& STB1 & $67.8 \pm 5.56$ & $978.3 \pm 150.6$ \\
Day 5 & Control & $6.2 \pm 1.03$ & $938.3 \pm 195.06$ \\
& STB1 & $6 \pm 1.32$ & $988.8 \pm 159.2$ \\
Day 7 & Control & $4.34 \pm 0.76$ & $990.23 \pm 139.8$ \\
& STB1 & $4.16 \pm 0.49$ & $994.52 \pm 172.48$ \\
\hline
\end{tabular}

a STB1 represents treatment with Acinetobacter calcoaceticus STB1 strain and Control represents treatment without any bacterial strain. Means and standard deviations were placed together in the form of mean of five different replicates $\pm S D$. Statistical analyses revealed that there is no statistically significant difference between same day samples for survival rates $(P>0.05)$.

would not have any toxic or growth retarding affects on aquatic organisms.

\section{Acknowledgments}

We would like to thank Alper Devrim Ozkan, Yavuz Selim Dagdas, and Erdem Akinci for technical help. This work was supported by grants from the Scientific and Technological Research Council of Turkey (TUBITAK 1090673) and the State Planning Organization of Turkey (DPT).

\section{References}

Andrade do Canto, C.S., Rodrigues, J.A., Ratusznei, S.M., Zaiat, M., Foresti, E., 2008 Feasibility of nitrification/denitrification in a sequencing batch biofilm reactor with liquid circulation applied to post-treatment. Bioresource Technology 99, 644-654.

Fagerbakke, K.M., Heldal, M., Norland, S., 1996. Content of carbon, nitrogen, oxygen, sulfur and phosphorus in native aquatic and cultured bacteria. Aquatic Microbial Ecology 10, 15-27.

Greif, D., Wesner, D., Regtmeier, J., Anselmetti, D., 2010. High resolution imaging of surface patterns of single bacterial cells. Ultramicroscopy 110, 1290-1296.

Joo, H.S., Hirai, M., Shoda, M., 2005. Characteristics of ammonium removal by heterotrophic nitrification-aerobic denitrification by Alcaligenes faecalis no. 4. Journal of Biosciences and Bioengineering 100, 184-191.
Jorgensen, T.C., Weatherley, L.R., 2003. Ammonia removal from wastewater by ion exchange in the presence of organic contaminants. Water Research 37, 1723-1728.

Khardenavis, A.A., Kapley, A., Purohit, K.J., 2007. Simultaneous nitrification and denitrification by diverse Diaphorobacter sp. Applied Microbiology and Biotechnology 77, 403-409.

Nejidat, A., 2005. Nitrification and occurrence of salt-tolerant nitrifying bacteria in the Negev desert soils. FEMS Microbiology Ecology 52, 21-29.

NJDEP, 1997. Facts; Nitrate and Nitrite in Drinking Water? Department of Health and Senior Services, New Jersey. online at: http://www.state.nj.us/health/eoh/ hhazweb/nitrate.pdf.

Nunes, B.S., Carvalho, F.D., Guilhermino, L.M., Stappen, G.V., 2006. Use of the genus Artemia in ecotoxicity testing. Environmental Pollution 144, 453-462.

Rijpens, N., Vlaemynck, G., Rossau, R., Herman, L., Jannes, G., 1998. Unidentified Listeria-like bacteria isolated from cheese. Letters in Applied Microbiology 27, 198-202.

Rostron, W.M., Stuckey, D.C., Young, A.A., 2001. Nitrification of high strength ammonia wastewaters: comparative study of immobilization media. Water Research 35, 1169-1178.

Russo, R.C., 1985. Ammonia, nitrite, and nitrate. In: Rand, G.M., Petrocelli, S.R. (Eds.), Fundamentals of Aquatic Toxicology and Chemistry. Hemisphere Publishing Corp, Washington, DC, pp. 455-471.

Schmidt, T., Schaechter, M. (Eds.), 2011. Low-Nutrient Environments. Topics in Ecological and Environmental Microbiology. Academic Press, Department of Microbiology and Molecular Genetics, Michigan State University, pp. 437-455.

Sinha, B., Annachhatre, A.P., 2006. Partial nitrification-operational parameters and microorganisms involved. Reviews in Environmental Sciences and Biotechnology 6, 285-313.

Taylor, S.M., He, Y., Zhao, B., Huang, J., 2009. Heterotrophic ammonium removal characteristics of an aerobic heterotrophic nitrifying-denitrifying bacterium, Providencia rettgeri YL. Journal of Environmental Sciences 21, 1336-1341.

US EPA, 1993. Process Design Manual for Nitrogen Control. United States Environmental Protection Agency, Washington, DC.

US EPA, 2009. Draft 2009 Update of Aquatic Life Ambient Water Quality Criteria for Ammonia - Freshwater. United States Environmental Protection Agency, Washington, DC.

Verschuere, L., Rombaut, G., Huys, G., Dhont, J., Sorgeloos, P., Verstraete, W., 1999. Microbial control of the culture of Artemia juveniles through preemptive colonization by selected bacterial strains. Applied and Environmental Microbiology 65, 2527-2533.

WHO, 1990. Ammonia Health and Safety Guide. World Health Organization, Geneva. online at: http://www.inchem.org/documents/hsg/hsg/hsg037. htm\#SubSectionNumber:1.3.2.

Wu, Y.H., Chu, Y.N., 2007. Development of a self-cleaning rotating drum Artemia nauplii concentrator. Aquaculture Engineering 36, 51-60.

Yang, X.P., Wang, S.M., Zhang, D.W., Zhou, L.X., 2011. Isolation and nitrogen removal characteristics of an aerobic heterotrophic nitrifying-denitrifying bacterium, Bacillus subtilis A1. Bioresource Technology 102, 854-862.

Zhao, B., He, Y.L., Hughes, J., Zhang, X.F., 2010. Heterotrophic nitrogen removal by a newly isolated Acinetobacter calcoaceticus HNR. Bioresource Technology 101, 5194-5200. 